DOI: http://doi.org/10.4038/jrrisl.v100i0.1897

Journal of the Rubber Research Institute of Sri Lanka (2020) 100, 22-37

\title{
Capital assets impact on rubber farming in Moneragala in Sri Lanka: Rubber smallholders' perception
}

\author{
P K K S Gunarathne*, T M S P K Tennakoon** and Jagath C Edirisinghe*** \\ * Rubber Research Institute of Sri Lanka, Telewala Road, Ratmalana, Sri Lanka \\ ** Department of Geography, University of Sri Jayewardenepura, Gangodawila, \\ Nugegoda, Sri Lanka \\ *** Department of Agribusiness Management, Faculty of Agriculture and Plantation \\ Management, Wayamba University of Sri Lanka, Makandura
}

\begin{abstract}
Rubber farming in Moneragala district has been considered as an initiative to poverty alleviation and livelihood sustainability. Thus rubber farming was introduced to eight Divisional Secretariat (DS) divisions in the District. Yet, no study was found which addresses the impact of capital assets on rubber farming. Hence, a questionnaire survey was conducted in 2019 to evaluate rubber smallholders' perception on the impact of capital assets on rubber farming at the household and community level and also to identify the factors affecting the perception. Several were defined to capture changes in the capital asset categories of livelihoods, viz. financial, physical, natural, human, and social assets at both household and community levels. A five-point modified Likert-type scale was used to measure the extent of agreement of variables and weighted values were used to derive the mean score of each item. The mean perception score of respondents was calculated and their key socio-economic characteristics were measured. Perception of the respondents was categorized as, least, moderate and most favourable groups using the confidence interval method. Descriptive methods and Spearman rank correlation analysis were used in data analysis. The indicators used to evaluate the Perceptions on the Impact of Rubber Farming on Capital Assets (PIRFCA) were reliable with Cronbach's alpha exceeding 0.7. The overall perception level of RSs on the impact of rubber farming on livelihood assets at the household and community level was under the most favourable level. The level of education, age, the experience of farming and rubber farming, rubber farming extent, training programmes attended, contacts with fellow farmers and income from rubber farming were significantly correlated with PIRFCA, while gender and type of job did not have a significant relationship. Accordingly, RSs' perceived perception explained that rubber farming is the main source of their livelihood developments. Hence, policymakers should critically consider these factors when expanding rubber farming to non-traditional areas in the country as a livelihood strategy.
\end{abstract}

Key words: capital assets, impact of rubber farming, perception 
P K K S Gunarathne et al.

\section{Introduction}

The rubber cultivation is expanded to the agro-ecological regions, IL1c, IL 2 and IM $2 b$ belonging to the eight Divisional Secretariat (DS) divisions of Moneragala District, with the aim of transforming the existing system of shifting cultivation and cash crop farming to more ecologically stable cultivation systems with proper land management by smallholders. Rubber Farming (RF) was originally expanded to Moneragala with two major objectives in the Millennium Development Goals; namely, poverty alleviation and livelihood sustainability (Wijesuriya et al., 2011). However, during the period from the year 2000 to 2005, a considerable increase was observed in the rubber extent due to the adoption of RF by the smallholders in Moneragala (Dissanayake et al., 2005). At present, the total extent of rubber smallholdings in Moneragala is about 4,402 ha which involves 7,802 holdings in number, out of which, the economically productive harvesting extent is only 689 ha which accounts for $20 \%$ (7,802 holdings). However, only about $5 \%$ of cultivable lands are being utilized for rubber cultivation in Moneragala (MPI, 2017). On the other hand, Moneragala is the first intermediate zone RF practice that has been implemented in Sri Lanka.

There is a positive relationship between the growth of agriculture and poverty alleviation with the engagement of the majority of rural people in the agriculture sector. Agricultural development programmes would affect poverty reduction and focus on up-lifting of the
Capital Assets (CA) in rural areas. The Government of Sri Lanka implemented policies and strategies for expanding RF among the smallholders to reduce poverty in rural areas, to enhance the $\mathrm{CA}$ of the peasant smallholders and finally, to uplift the socioeconomic status of them. Thus, the public eye by the RF as a livelihood strategy in the nontraditional area has focused on the development of the CA in both levels of household and community (Wijesuriya et al., 2011). Therefore, the adaptability of the RF as a livelihood strategy may affect the CA of the rural smallholders at the household level and community level both positively and negatively.

Many studies were found in the literature in expansion of RF into rural areas and its effects on the farmers' socioeconomic status (Kromkratoke and Suwanmaneepong, 2017; Kongmanee et al., 2020). Also, the most of studies of RF in Moneragala have only focused on the aspects of extension and technical matters. Therefore, there is a research gap in the studies of CA impact of RF in Moneragala. This study contributes new insights by comparing independently observed changes in usage of land and associated CA changes, with perceptions of those changes, and the impacts of change in the lives of rural people. In the light of the above, the success of RF during and after the establishment of RF would be a major learning curve, so to mention, and if recorded properly, its successes and failures would be of enormous value for planting development programmes which are to be planned in the future in Sri Lanka. 
As noted in the background of the research problem, it is clear that RF is expected to change the $\mathrm{CA}$ and linkage between RF on the household and community level. This study, therefore, attempts to make a point of filling the prevailing gap in the literature and to uncover the impact of RF on CA of smallholders through achieving the objectives; viz. to study the perception on the impact of RF on CA of smallholders based on household and community level in Moneragala and identify the factors affecting to the perception.

\section{Methodology}

Sampling procedure and data collection The study was conducted in the Moneragala District $\left(6.872575^{\circ} \mathrm{N}\right.$ $81.33728^{\circ} \mathrm{E}$ ) in Sri Lanka during 2019. The farmer survey was conducted with 511 Rubber Smallholders (RSs) in eight rubber growing DS divisions (Table 1). The stratified sampling technique was applied according to the distribution of RSs in each division. Pre-tested questionnaire and field observations were used to collect data and information from the RSs. The questionnaire consists of questions from the key general information of RSs and perception on the impact of RF on the development of CA on RSs based on the household and community level.

The qualitative methodology was selected for this study because of its ability to elicit experiences through a descriptive, reflective, interpretive and engaging research framework (Creswell, 2009). Some research has been conducted about perception, including
Table 1. The selected sample sizes of rubber smallholders from different DS divisions in Moneragala District

\begin{tabular}{|c|c|}
\hline DS division & No. of smallholders \\
\hline Bibila & 43 \\
\hline Madulla & 65 \\
\hline Madagama & 92 \\
\hline Siyabalanduwa & 4 \\
\hline Moneragala & 99 \\
\hline Badalkumbura & 182 \\
\hline Wellawaya & 19 \\
\hline Buttala & 7 \\
\hline Total & 511 \\
\hline
\end{tabular}

factors related to agriculture such as extension (Moore, 1988), adoption of farming systems (Williams and Wise, 1997), environment (Bruening et al., 1992) and information technologies (Ahmed et al., 2004). Perception is the cognitive process where people used to make sense out of the environment by selecting, organizing and interpreting information from the environment (Lindsay and Norman, 1977). Attitudes affect perceptions and vice versa. Hikson and Keith, (2000) mentioned, that assessing farmers' perceptions is an important means to evaluate their knowledge level on a particular issue, as perception refers to an individual's current appraisal of an object or program. People base their perceptions on past experience and knowledge; therefore, if a person has limited knowledge and experience about a topic, then they cannot accurately perceive it or form an opinion on it (May, 1969; Bohlander and Snell, 2004). Therefore, the impact of RF on RSs' CA was investigated by RSs' perception to gain deeper understanding 
P K K S Gunarathne et al.

through experiences. So that it might be helpful to the concerned policymakers to have the field level idea during policy making and implementation process.

\section{Measuring the impact on capital asset} The CA impact of this study was considered whether and to what extent the RF has affected peoples' livelihoods in Moneragala area. The hypothesis was that increasing trade of rubber products (Latex and Ribbed Smoke Sheets - RSS) would provide income, employment, changing environment and other opportunities for RSs to improve their welfare in the household and community level. According to the definitions of CA that include non-financial aspects of sustainable rural livelihoods framework was used (Carney, 1998, DFID, 2005) to guide the selection of indicators (Table 2) (DFID, 2005; IFAD, 2007) and these may be tangible and intangible assets
(Eldis, 2010; Lindenberg, 2002; Tennakoon, 2002). Accordingly, items (indicators) were defined to capture changes in the five CA categories that form the main components of RSs' livelihoods, namely financial, physical, natural, human, and social assets and these categories have been widely adopted as an organizing principle of RSs' CA impact (Bebbington, 1999: Bossel, 2001; Campbell et al., 2001; Cramb et al., 2004; Gottret and White, 2001).

Developing the items to measure the perception on capital assets at the household level

The perception of each indicator was presented as an item/statement (Segnon, 2015). Twelve household level items were selected to measure the CA with the discussion of the experts of the rubber sector and literature review (Table 3 ).

Table 2. Definitions of the five capital assets

\begin{tabular}{ll}
\hline Type of capital asset & Definition \\
\hline Natural capital & $\begin{array}{l}\text { The natural resource stocks from which resource flows useful for } \\
\text { livelihoods are derived (land, water, wildlife, biodiversity and } \\
\text { environmental resources) }\end{array}$ \\
\hline Physical capital & $\begin{array}{l}\text { The basic infrastructure (transport, shelter, water, energy and } \\
\text { communications) and the production equipment and means that } \\
\text { enable people to pursue their livelihoods }\end{array}$ \\
\hline Social capital & $\begin{array}{l}\text { The social resources (networks, membership of groups, } \\
\text { relationships of trust, access to wider institutions of society) upon } \\
\text { which people draw in pursuit of livelihoods }\end{array}$ \\
\hline Human capital & $\begin{array}{l}\text { The skill, knowledge, ability and good health of the labour which } \\
\text { are important to pursue different livelihood strategies }\end{array}$ \\
\hline Financial capital & $\begin{array}{l}\text { The financial resources which are available to people (savings, } \\
\text { supplies of credit or regular remittances or pensions) and which } \\
\text { provide them with different livelihood options }\end{array}$ \\
\hline
\end{tabular}


Impact of capital assets on rubber farming

Table 3. The selected items to measure the capital assets at the household level

\begin{tabular}{ll}
\hline Type of capital & Items \\
\hline Natural capital & HN 1: Improve soil condition in the rubber land \\
& HN 2: Protects water resources in the rubber land \\
\hline Physical capital & HP 1: Development of living house \\
& HP 2: Buying vehicles \\
& HP 3: Buying household durables \\
\hline Social capital & HS 1: Improves social relationships \\
& HS 2: Access to wider institutions of society \\
\hline Human capital & HH 1: Improve the health status of family members \\
& HH 2: Improve the nutritional status of family members \\
\hline Financial capital & HF 1: Continuous income throughout the year \\
& HF 2: Household savings were developed \\
& HF 3: Access to credit was improved \\
\hline
\end{tabular}

Developing the items to measure the perception on capital assets at the community level

To measure the impact of RF on the community level, a set of items relevant to each CA was selected, based on the discussion of the experts of the rubber sector and also through literature review. At the community level, indicators address the effects on overall community assets in the rubber growing areas (Dove
1994; Ashley and Hussein, 2000). Theoretically, a strong productionconsumption system might also contribute to economic performance at the national level through job creation and foreign exchange earnings. However, in this study, national-level impacts were not analysed. Table 4 shows the items selected to measure the $\mathrm{CA}$ at the community level.

Table 4. The selected items to measure the capital assets at the community level

\begin{tabular}{ll}
\hline Type of capital & Items \\
\hline Natural capital & CN 1: Reduce soil erosion \\
& CN 2: Protects water resources in the area \\
\hline Physical capital & CP 1: Development of access roads to access farming lands \\
& CP 2: Development of bridges to access the farming lands \\
\hline Social capital & CS 1: Improves the socio-cultural cohesion \\
& CS 2: Effective community organization \\
\hline Human capital & CH 1: Enhance the full-time employment opportunities \\
& CH 2: Enhance the part time employment opportunities \\
\hline Financial capital & CF 1: Improves the community financial resources \\
& CF 2: Access to credit facilities \\
\hline
\end{tabular}


P K K S Gunarathne et al.

\section{Measurement of items}

The assessment of CA outcomes was based on the last ten-year reference period (2009 to 2019), due to no baseline data regarding livelihood status, the assessment relies on the expert judgment of changes on indicators. The ten year period was deemed sufficiently long to be able to observe changes, but short enough for the assessor to make reliable judgments of changes based on the information available. Changes that occurred before 2009 were not captured in the assessment. Each item was assessed according to the questionnaire. RSs were asked to mark their opinion on these items based on a five-point ordinal scale (Babbie, 2010). A five-point modified Likert-type scale was used to measure the extent of agreement; strongly agree, agree, neutral, disagree and strongly disagree (Likert, 1932). The weighted values on the Likert-scales were used to derive the mean score of each indicator. The weights assigned to the responses were $4,3,2,1$ and 0 , respectively. The values on the Likertscales were used to derive the mean score of each item and then the aggregate mean scores of the five capital aspects were calculated (Jayasinghe-Mudalige and Henson, 2006). The mean perception score of a respondent was determined by adding up the weighted values for all the responses against all the items and RSs' key socio-economic characteristics.

\section{Data analysis}

Respondent's perception was measured by summing up the score of each item in the questionnaire. The mean perception score in each capital was measured. The respondents were separated into three perception categories viz. most favourable, favourable and least favourable attitude based on their total score by using the confidence interval method (Fisher, 1935) and categorized the respondents as follows; Least favourable group $=$ Below $\mathrm{X}-1.96 * \mathrm{SE}$, Favourable group $=$ Between $X$ $1.96 * \mathrm{SE}$ and Between $\mathrm{X}+1.96 * \mathrm{SE}$ and Most favourable group $=$ Between $\mathrm{X}+$ $1.96 * \mathrm{SE}$ (SE is the standard error). Cumulative frequency distribution and percentage analysis were used to quantify groups. Statement-wise perception was evaluated by using descriptive statistical methods. Descriptive methods and Spearman rank correlation analysis were used in data analysis employing STATA 15.0. The scale reliability of the statements was tested using the Cronbach alpha value. The perception analysis of the alpha values exceeding 0.7 was considered sufficient (Lord and Novick, 2008). The aggregate mean scores of the five CA and mean perception score of a respondent were measured at the household and community level. RSs' socio-economic characteristic and their influence on the perception of $\mathrm{CA}$ impacts were also analysed.

\section{Results and Discussion Key socio-economic profile of the farmers}

The key socio-economic characteristics of RSs (Table 5) were used to identify the relationships with perception (Shankaraiah and Swamy, 2012). The age of the rubber farmers varied from 21- 
78 years and the majority was young and were 40 years or below. The half of the sample of the smallholders had studied up to $\mathrm{O} / \mathrm{L}$ while about $9 \%$ of smallholders had studied up to grade 5 and $21 \%$, up to advanced level. Around $30 \%$ of smallholders had less than 15 years of experience in farming, while $36 \%$ were reported to have more than 36 years of experience. The mean land size was 0.62 ha. About $50 \%$ of the lands were less than 2.9 ha in size.

Table 5. Distribution of key socio-economic characteristics of rubber smallholders

\begin{tabular}{|c|c|c|}
\hline $\begin{array}{l}\text { Key socio-economic characteristics } \\
\text { and their categories }\end{array}$ & $\%$ & $\begin{array}{l}\text { area consider RF as the most favourable } \\
\text { livelihood strategy on their impact on }\end{array}$ \\
\hline Age (years) & & CA (Table 7). Whilst, $30 \%$ of the RSs \\
\hline$<40$ & 42 & consider it as a favourable livelihood \\
\hline $41-60$ & 38 & strategy, $16 \%$ of the RSs consider it as \\
\hline$>61$ & 20 & the least favourable. However, overall \\
\hline Range & $21-78$ & PIRFCA is considered as the most \\
\hline Education level & & favourable level. \\
\hline Up to grade 5 & 09 & Table 8 explains the category of PIRFCA \\
\hline Up to grade 8 & 19 & at the household and community level. \\
\hline Up to Ordinary Level & 51 & More than $50 \%$ of the RSs in this study \\
\hline Up to Advanced Level & 21 & area consider RF as the most favourable \\
\hline Experience in farming (years) & & livelihood strategy on their $\mathrm{CA}$ at \\
\hline$<15$ & 31 & household level while $28 \%$ of the \\
\hline $16-25$ & 15 & farmers considering it as a favourable \\
\hline $26-35$ & 18 & livelihood strategy and $8 \%$ of the RSs \\
\hline$>36$ & 36 & considering it as a least favourable \\
\hline Range & $5-55$ & livelihood strategy. Nearly half of the \\
\hline Land size (ac.) & & RSs of the sample in this study area are \\
\hline$<1$ & 7.5 & considering the RF as the most \\
\hline $1-1.9$ & 38 & favourable livelihood strategy $(44 \%)$ on \\
\hline $2-2.9$ & 7 & their $C A$ at the community level \\
\hline $3-3.9$ & 22.5 & However favourable and \\
\hline $4-4.9$ & 21 & However, tavourable and least \\
\hline$>=5$ & 4 & favourable percentages are 32 and 24 \\
\hline Mean & 1.5 & 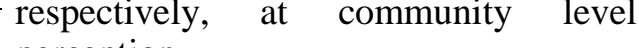 \\
\hline
\end{tabular}

Consistency test of perceptions of rubber smallholders on the impact of capital assets

Table 6 shows the mean and reliability coefficients (Cronbach alpha values) of the indicators used to evaluate the Perceptions on the Impact of Rubber Farming on the Capital Assets (PIRFCA) at the household and community level by RSs. As all items exceed 0.7 (Cronbach Alpha value), the indicators used in this study are valid and reliable to explore the perceptions of RSs.

Distribution of rubber smallholders by perception categories

More than $50 \%$ of the RSs in this study area consider RF as the most favourable of the RSs the least favourable. However, overall PIRFCA is considered as the most favourable level. at the household and community level. More than $50 \%$ of the RSs in this study household level while $28 \%$ of the favourable livelihood strategy. Nearly half of the RSs of the sample in this study area are their CA at the community level. However, favourable and least 
Table 6. The reliability of perception variables

\begin{tabular}{lllll}
\hline Type of capital & \multicolumn{2}{c}{ Household level } & \multicolumn{2}{c}{ Community level } \\
\cline { 2 - 5 } & Cronbach Alpha & SD & Cronbach Alpha & SD \\
\hline Natural capital & 0.8777 & 0.3322 & 0.7777 & 0.3555 \\
Physical capital & 0.7807 & 0.6964 & 0.7507 & 0.6567 \\
Social capital & 0.7277 & 0.4183 & 0.7531 & 0.5183 \\
Human capital & 0.9833 & 0.3864 & 0.7621 & 0.4868 \\
Financial capital & 0.9817 & 0.6924 & 0.7111 & 0.7930 \\
\hline
\end{tabular}

$\mathrm{SD}=$ Standard deviation

Table 7. Distribution of rubber smallholders by overall perception categories

\begin{tabular}{lll}
\hline Category & Mean perception score & \% of respondents \\
\hline Most favourable & $>3.382$ & 54 \\
Favourable & $3.381-3.300$ & 30 \\
Least favourable & $<3.301$ & 16 \\
\hline
\end{tabular}

Table 8. Distribution of rubber smallholders by perception categories

\begin{tabular}{lllll}
\hline Category & \multicolumn{2}{c}{ Household level } & \multicolumn{2}{c}{ Community level } \\
\cline { 2 - 5 } & $\begin{array}{l}\text { Mean } \\
\text { perception } \\
\text { score }\end{array}$ & $\begin{array}{l}\text { Percentage } \\
\text { of } \\
\text { respondents }\end{array}$ & $\begin{array}{l}\text { Mean } \\
\text { perception } \\
\text { score }\end{array}$ & $\begin{array}{l}\text { Percentage } \\
\text { of } \\
\text { respondents }\end{array}$ \\
\hline Most favourable & $>3.521$ & 64 & $>3.243$ & 44 \\
Favourable & $3.520-3.485$ & 28 & $3.242-3.119$ & 32 \\
Least favourable & $<3.484$ & 08 & $<3.118$ & 24 \\
\hline
\end{tabular}

\section{Analysis of item-wise perception}

The mean scores of PIRFCA at household level are given in Table 9. The assessment shows that the mean of overall PIRFCA at the household level is 3.74. The highest mean score was recorded from physical capital (3.69) and the lowest (3.73) was recorded from social and financial CA. The mean scores of natural and human capitals were 3.81 and 3.78 , respectively.
The mean scores of PIRFCA at the community level are given in Table 10 . The assessments show that the mean of overall PIRFCA at the community level is 3.27 while the highest mean score was recorded from human capital (3.99) and the lowest (2.16) was recorded from physical capital. The mean scores of financial, natural and social assets were $3.53,3.89$ and 2.76 respectively. 
$\underline{\text { Impact of capital assets on rubber farming }}$

Table 9. Mean scores of the items and capital assets to assess the perception at household level

\begin{tabular}{|c|c|c|c|}
\hline $\begin{array}{l}\text { Type of } \\
\text { capital }\end{array}$ & Items & $\begin{array}{l}\text { Mean } \\
\text { score of } \\
\text { items } \\
\end{array}$ & $\begin{array}{r}\text { Mean score } \\
\text { of capital } \\
\text { assets } \\
\end{array}$ \\
\hline $\begin{array}{l}\text { Natural } \\
\text { capital }\end{array}$ & $\begin{array}{l}\text { HN 1: Improve soil condition in the rubber land } \\
\text { HN 2: Protects water resources in the rubber land }\end{array}$ & $\begin{array}{l}3.835 \\
3.790\end{array}$ & 3.812 \\
\hline $\begin{array}{l}\text { Physical } \\
\text { capital }\end{array}$ & $\begin{array}{l}\text { HP 1: Development of living house } \\
\text { HP 2: Buying vehicles } \\
\text { HP 3: Buying household durables }\end{array}$ & $\begin{array}{l}3.730 \\
3.645 \\
3.715 \\
\end{array}$ & 3.696 \\
\hline $\begin{array}{l}\text { Social } \\
\text { capital }\end{array}$ & $\begin{array}{l}\text { HS 1: Improves social relationships } \\
\text { HS 2: Access to wider institutions of society }\end{array}$ & $\begin{array}{l}3.690 \\
3.770 \\
\end{array}$ & 3.730 \\
\hline $\begin{array}{l}\text { Human } \\
\text { capital }\end{array}$ & $\begin{aligned} \text { HH 1: } & \text { Improve the health status of family } \\
& \text { members } \\
\text { HH 2: } & \text { Improve the nutritional status of family } \\
& \text { members }\end{aligned}$ & $\begin{array}{l}3.825 \\
3.735\end{array}$ & 3.780 \\
\hline $\begin{array}{l}\text { Financial } \\
\text { capital }\end{array}$ & $\begin{array}{l}\text { HF 1: Continuous income throughout the year } \\
\text { HF 2: Household savings were developed } \\
\text { HF 3: Access to credit was improved }\end{array}$ & $\begin{array}{l}3.700 \\
3.730 \\
3.760 \\
\end{array}$ & 3.730 \\
\hline
\end{tabular}

Table 10. Mean scores of the items and capital assets to assess the perception at the community level

\begin{tabular}{|c|c|c|c|}
\hline $\begin{array}{l}\text { Type of } \\
\text { capital }\end{array}$ & Items & $\begin{array}{l}\text { Mean score } \\
\text { of items }\end{array}$ & $\begin{array}{l}\text { Mean score of } \\
\text { capitals }\end{array}$ \\
\hline $\begin{array}{l}\text { Natural } \\
\text { capital }\end{array}$ & $\begin{array}{l}\text { CN 1: Reduce soil erosion } \\
\text { CN 2: Protects water resources in the area }\end{array}$ & $\begin{array}{l}3.860 \\
3.932 \\
\end{array}$ & 3.896 \\
\hline $\begin{array}{l}\text { Physical } \\
\text { capital }\end{array}$ & $\begin{array}{l}\text { CP 1: Development of access roads to } \\
\text { access farming lands } \\
\text { CP 2: Development of bridges to access } \\
\text { the farming lands }\end{array}$ & $\begin{array}{l}2.215 \\
2.112\end{array}$ & 2.163 \\
\hline $\begin{array}{l}\text { Social } \\
\text { capital }\end{array}$ & $\begin{array}{l}\text { CS 1: Improves the socio-cultural } \\
\text { cohesion } \\
\text { CS 2: Effective community organization }\end{array}$ & $\begin{array}{l}3.324 \\
2.205\end{array}$ & 2.765 \\
\hline $\begin{array}{l}\text { Human } \\
\text { capital }\end{array}$ & $\begin{array}{l}\mathrm{CH} \text { 1: Enhance the full-time employment } \\
\text { opportunities } \\
\mathrm{CH} \text { 2: Enhance the part time employment } \\
\text { opportunities }\end{array}$ & $\begin{array}{l}3.941 \\
3.992\end{array}$ & 3.996 \\
\hline $\begin{array}{l}\text { Financial } \\
\text { capital }\end{array}$ & $\begin{array}{l}\text { CF 1: Improves the community financial } \\
\text { resources } \\
\text { CF 2: Access to credit facilities }\end{array}$ & $\begin{array}{l}3.514 \\
3.559\end{array}$ & 3.536 \\
\hline Mean scor & f overall perception at the community level & & 3.27 \\
\hline
\end{tabular}


P K K S Gunarathne et al.

\section{Perception of the natural capital assets development}

From the items which assessed the impact on natural capital assets, the HC1 (improve soil condition in the rubber land) had the highest mean with (3.83) and $\mathrm{HC} 2$ (protects water resources in the rubber land) in the rubber land second. The overall perception on improving natural capital development is under the most favourable level (mean $=3.81$ ) at household level while, the CN2 (protects water resources in the area) had the highest mean with (3.93) and CN1 (reduce the soil erosion in the area) was the second. However, the overall perception on improving natural capital assets development is under the most favourable level in (mean =3.89) at community level. Rubber is a perennial tree crop and it has a deep rooting system and a closed canopy. Therefore, rubber plantations have the ability to reduce the high-intensity of rains and prevent soil erosion (Samarappuli et al., 2005). From an ecological point of view, rubber plantations can be considered as a selfsustaining environmentally acceptable eco-system, which are capable of mitigating extreme weather conditions and protecting biodiversity (Samarappuli et al., 2005). One of the main ecological services of the rubber plantation is carbon sequestration which was estimated as $1296 \mathrm{MT} / \mathrm{ha}$, at the end of 24 years of the life cycle (Munasinghe et al., 2011). Therefore, the environmental impact of rubber cultivation is a crucial factor to the Moneragala as this district covers different agro-ecological regions.

\section{Perception of the physical capital development}

From the indicators used for evaluating the impact on physical capital, HP1 (Development of living house) has the highest mean (3.73) while, the means of HP2 (Buying vehicles) and HP1 (Buying household durables) are 3.64 and 3.71, respectively. The overall perception on improving physical capital development is under the satisfactory level (mean =3.69). The CP1 (development of access roads for farming lands) had the highest mean with (2.21) and CP2 (development of bridge to access the farming lands) in the cultivated area second. However, the overall perception on improving natural capital development is under the least favourable level (mean $=2.16$ ) at the community level. RSs developed some access roads to their farms in Badalkumbura and Medagama areas, but reported cases were limited. RSs in this sample believe that rubber cultivation has the most favourable impact on physical capital development at household level.

\section{Perception of the social capital development}

The mean scores of items HS1 (improves the social relationships) and HS2 (access to wider institutions of society) are 3.69 and 3.77 , respectively. The overall perception on improving social capital development is under the most favourable level (mean =3.73) at household level. Considering the community level, the mean scores of indicators CS1 (improves the sociocultural cohesion) and CS2 
Impact of capital assets on rubber farming

(effectiveness of community organization) are 3.32 and 2.20, respectively. The overall perception on improving social capital development is under the least favourable level (mean =2.76). Most of the RSs in the Monaragala are members of the Thurusaviya rubber society. This society have welfare and credit schemes to the members and society members share the labour among themselves for free of charge to engage in agronomic practices of rubber cultivation, such as planting, weeding and manuaring. RF is considered as a subculture in the agricultural sector in Moneragala and it is important to maintain the social integrity of non-traditional RF areas (Dissanayake and Wijesuriya, 2012; Wijesuriya et al., 2008).

\section{Perception of the human capital development}

From the two indicators used for evaluating the impact on human capital, the HH1 (improve the health status of family members) has the highest mean score (3.82). The overall perception on improving human capital development is under a most favourable level (mean =3.78). Wijesuriya et al., (2012) reported that most RSs spend more than $95 \%$ of their income on food and beverages and health care. From the indicators used for evaluating the impact on human capital based on community level, indicator $\mathrm{CH} 2$ (enhance the part-time employment opportunities) has the highest mean (3.99) whilst, the means of $\mathrm{CH} 1$ (enhance the full-time employment opportunities) is 3.94 . These findings support the human development programes operated by RRISL with the aim of providing new job opportunities as harvesters and sheet makers have been conducted Thus, many types of job opportunities were created as latex collectors and transporters, RSS collectors/dealers, input sellers of rubber farming and private advisors due to the rubber farming in Moneragala (RRISL, 2012).

\section{Perception of the financial capital development}

The mean scores of the perception on HF1 (continuous income throughout the year), HF2 (enhance the household savings) and HF3 (access to credit facilities) are 3.70, 3.73 and 3.76, respectively. The overall perception on improving financial capital development is under the satisfactory level $($ mean=3.73) at the household level. From the indicators used for evaluating the impact on financial capital, indicator CF2 (access to credit facilities) has the highest mean (3.59) whilst, the means of CF1 (improves the community financial resources) was 3.51. The overall perception on improving the financial capital assets development is under the most favourable level (mean $=3.53$ ). Although most of the RSs in the study area are engaged in seasonal farming, their main source of income is rubber farming throughout the year. Further, the main economic objective of RSs is to maximize their family income (Dissanayake and Wijesuriya, 2012). RSs in this sample believe that RF has an 
P K K S Gunarathne et al.

impact on this financial capital development on their livelihoods.

\section{Influence of socio-economic} characteristics of rubber smallholders' on their perceptions

This section examines the impact of the key socio-economic characteristics of the RSs on their PIRFCA. Except for gender and type of the job, the other eight variables had a significant positive correlation with the farmer's perception at 0.001 significant level (Table 11). Age is negatively correlated with PIRFCA. Age is an important factor that determines the response of a person during various activities in his life. Rational decision making process also depends on age and a younger person has more ability to adapt and respond to an activity (particularly, in communication and understanding) than an older person (Tsur et al., 1990). RSs' PIRFLA is positively correlated with the level of education. This is an indication that more the education level of RSs, the greater their ability to perceive the economic and non-economic benefits from the RF. Education helps people to gain knowledge and understanding about a particular idea and makes them more communicative (Khan, 2005).

Farming and RF experience showed a significant positive influence on PIRFCA. With the accumulated farming experience RSs can compare the different farming systems with RF with regard to CA. Experience is very important in any field of life to gain benefits and quality (Khan, 2005). It develops the communication network among the RSs and also helps to share the knowledge, experience and attitudes among them. The extent of cultivation of RF positively influenced PIRCL. It means that the perceived livelihood benefits from large scale $\mathrm{RF}$ is comparatively high.

Table 11. Rubber smallholders' socio-economic characteristic and their influence on their perceptions

\begin{tabular}{lll}
\hline Farmers' characteristics & Coefficient & P value \\
\hline Gender & 0.0599 & 0.3994 \\
Level of education (years) & $0.9704^{*}$ & 0.0000 \\
Age (years) & $-0.9764^{*}$ & 0.0000 \\
Type of the job (full time, part-time) & 0.0944 & 0.1835 \\
Experience of farming (years) & $0.3562^{*}$ & 0.0000 \\
Experience of rubber farming (years) & $0.9600^{*}$ & 0.0000 \\
Total cultivated rubber land extent (ha) & $0.9796^{*}$ & 0.0000 \\
Participated training/extension programmes & $0.9591^{*}$ & 0.0000 \\
\hline
\end{tabular}


Participation in training/extension programs is positively correlated with PIRFCA. Agricultural extension is responsible for technology transfer and plays a significant role in increasing productivity, income and profit (Luqman et al., 2004). Agricultural education, information and skill development are the main concerns of agricultural extension agencies (Farooq et al., 2007). Thus agricultural extension organizations are entrusted with the primary task of educating and disseminating the latest agricultural technologies to the farmers, using various extension teaching methods like individual, group and mass contact methods. Therefore, by participating the programmes conducted by RRISL and RDD, RSs can gain knowledge and skill on rubber farming and its impact. Contacts with other RSs for advisory purposes is positively correlated with PIRFCA. Advisory contacts are necessary for RSs to gain practical knowledge and solve practical ongoing problems. These provide an opportunity to learn by doing. The income of RF is positively correlated with PIRFCA.

\section{Conclusion}

Indicators used to evaluate the perceptions of RSs on the PIRFCA at both of household and community level were valid and reliable. RSs perceived perception explained that RF is the main source of their CA developments. According to the findings, the perception of RSs towards the impact of RF on CA at household level and community level under most favourable level. Therefore,
RF can be expanded into non-traditional areas in the country as a livelihood strategy to enhance the development of CA. The level of education, the experience of farming and RF, rubber farming extent, participated training programmes, contacts with other RSs and income of RF are positively correlated with PIRFCA, while age is negatively correlated. Hence, policymakers should critically consider these factors in the programmes on expanding RF as a livelihood strategy.

\section{References}

Ahmed, S A, Karablieh, E K and Alkadi, A $S$ (2004). An investigation into the perceived farm management and marketing educational needs of farm operations in Jordan. Journal of Agricultural Education 45(3), 34-43.

Ashley, C and Hussein, K (2000). Developing methodologies for livelihood impact assessment: experience of the African Wildlife Foundation in East Africa. Working Paper 129. Overseas Development Institute, London, UK.

Babbie, E (2010). The Practice of Social Research. $12^{\text {th }}$ ed.; Wadsworth Publishing: Belmont, MA, USA, p.625.

Bebbington, A (1999). Capitals and capabilities: A framework for analysing peasant viability, rural livelihood and poverty. World Development 27(12), 2021-2044.

Bohlander, G and Snell, S (2004). Managing Human Resources, $13^{\text {th }}$ edition. Thomson Corporation, USA. 232-274.

Bossel, H (2001). Assessing viability and sustainability: a systems-based approach for deriving comprehensive indicator sets. Conservation Ecology 5(2), 12 
P K K S Gunarathne et al.

[online] URL: http://www. consecol.org/vol5/iss2/art12/.

Bruening, $\mathrm{H} \mathrm{T}$, Radhakrishma, R $\mathrm{B}$ and Rollins, T J (1992). Environmental issues: farmers' perception about usefulness of informational and organizational sources. Journal of Agricultural Education 33(2), 34-42.

Campbell, B, Sayer, J A, Frost, P, Vermeulen, S, Ruiz-Pérez, M, A. Cunningham, and Prabhu, R (2001). Assessing the performance of natural resource systems. Conservation Ecology 5(2), 22. [online] URL: http://www.consecol.org/vol5/iss2/art22/

Carney, D (1998). Sustainable rural livelihoods. What contributions can we make? Department for International Development (DFID), London, UK.

Cramb, R A, Purcell, T and Ho, T C S (2004). Participatory assessment of rural livelihoods in the central highlands of Vietnam. Agricultural Systems 81(3), 255-272.

Creswell, J W (2009). Research design: Qualitative, quantitative and mixed methods approaches. Thousand Oaks, CA: Sage.

Department for International Development (DFID) (2005). Sustainable livelihoods guidance sheets. Available online at: http://www.livelihoods.org/info/info_gui dancesheets.htm.

Dissanayake, D M A P and Wijesuriya, W (2012). Growing rubber in Uva, Northern and Eastern provinces in Sri Lanka: Importance of an effective institutional role: Journal of the Rubber Research Institute of Sri Lanka 92, pp.78-91.

Dissanayake, D M A P, Wijesuriya, W and Edirisinghe, J C (2005). Smallholder rubber sector in the Moneragala district: Potentials and Constraints. Bulletin of Rubber Research Institute of Sri Lanka 46, pp.25-31.
Dove, M R (1994). Marketing the rainforest: 'Green' panacea or red herring? AsiaPacific Issues 13, 1-7. East-West Centre, Honolulu, Hawaii.

Eldis (2010). Livelihoods Connect. Retrieved February 5, 2010, from Eldis: http://www. eldis.org/index.cfm?objectid =42B0EF43-E4B7-FB32-9CE720C904C B143A.

Farooq, S, Muhammad, S, Chaudhary, K M and Ashraf, I (2007). Role of print media in the dissemination of agricultural information among farmers. Pakistan Journal of Agricultural Science 44 (2), 378-380.

Fisher, R A (1935). The design of experiments. Edinberg: Oliver and Beyd.

Gottret, M A V N and White, D (2001). Assessing the impact of integrated natural resource management: challenges and experiences. Conservation Ecology 5(2),17. [online] URL: http:// www.consecol. org/vol5/iss2/art17/.

Hikson, M and Keith, L (2000). The attitudes and perceptions of high school administrators toward agricultural science teachers in Texas. Proceedings of the Southern Agricultural Education Research Conference. Lexington, KY.

IFAD (2007). Sustainable Livelihoods Approach (SLA). <http://www.ifad. org/sla/index.htm> [30 de Junio de 2009].

Jayasinghe-Mudalige, U K and Henson, S P E N C E R (2006). Use of confirmatory factor analysis techniques to overcome the problems of subjectivity and unobservability of incentives. Sri Lankan Journal of Applied Statistics 7, pp.71-89.

Khan, S A (2005). Introduction to extension education. In: Extension Methods $3^{\text {rd }}$ ed. (eds. R.A. Memon and E. Bashir). National Book Foundation, Islamabad, Pakistan. pp.3-32.

Kongmanee, Chaiya and Ahmed, Ferdoushi (2020). Assessing socio-economic 
Impact of capital assets on rubber farming

characteristics of FSC certified rubber farmers and their attitudes to apply FSC standards in rubber plantation: A case study in Thailand. International Journal of Management (IJM) 11(9), September 2020, pp.1359-1372, Available at SSRN: https://ssrn.com/abstract=371279 1.

Kromkratoke, W and Suwanmaneepong, S (2017). Socio-economic characteristics of rubber farmer in drought area in Sa Kaeo Province, Thailand. International Journal of Agricultural Technology 13(7.2), 1947-1957.

Likert, R A (1932). A technique for the measurement of attitude. Arc. Psychology, 147-167.

Lindenberg, M (2002). Measuring household -livelihood security at the family and community level in the developing world. World Development. Great Britain. 30(2), 301-318.

Lindsay, P and Norman, D A (1977). Human Information Processing: An introduction to psychology. Harcourt Brace Jovanovich, Inc.

Lord, F M and Novick, M R (2008). Statistical Theories of Mental Test Scores. IAP.

Luqman, M, Ahmad, M and Javed, A (2004). A study into the effectiveness of public sector extension after decentralization in district Muzaffargarh. Agricultural Science Journal of Pakistan 1, 68-70.

May, R (1969). Love and Will. Norton Press Limited, New York.

Moore, E G (1988). Perception of teacher educators in agriculture relating to agricultural and rural improvements in developing countries. Journal of the American Association of Teacher Educators in Agriculture 29(2), 713.

Munasinghe, E S, Rodrigo, V H L and Karunathilaka, P K W (2011). Carbon sequestration in mature rubber (Hevea brasiliensis Muell. Arg.) plantations with genotypic composition. Journal of the Rubber Research Institute of Sri Lanka 91, pp.36-48.

Rubber Research Institute of Sri Lanka (2010). Annual Review. Rubber Research Institute of Sri Lanka, Agalawatta, Sri Lanka, 144-149.

Samarappuli, L, Karunadasa, $\mathrm{P}$ and Mitrasena, U (2005). Soil management for higher productivity of rubber in Moneragala. Bulletin of Rubber Research Institute of Sri Lanka 46, pp.10-16.

Segnon, A C, Achigan-Dako, E G, Gaoue, O G, Ahanchédé, A (2015). Farmer's knowledge and perception of diversified farming systems in sub-humid and semiarid areas in Benin. Sustainability 7, 6573-6592.

Shankaraiah, N and Swamy, B K N (2015). Attitude of farmers and scientists towards dissemination of technologies through mobile message service (MMS). Tropical Agricultural Research 24(1), pp.31-41. DOI: http://doi.org/10.4038/tar.v24i1. 7987.

The Ministry of Plantation Industries. (2017). Plantation Sector Statistical Pocket Book. Sri Lanka. 100-150.

Thennakoon, Sunethra (2002). Influence of crop profitability, market, labour and land on smallholder cropping systems in rubber growing areas of Sri Lanka. School of Agricultural and Forest Sciences, University of Wales Bangor, United Kingdom. (Un published $P h D$ Thesis).

Tsur, Y, Sternberg, M and Hochman, E (1990). Dynamic modeling of innovation process: Adoption with risk aversion and learning. Oxford Econ. Papers 42 (1), 336-355.

Wijesuriya, B W, Dissanayake, D M A P, Gunaratne, P K K S, Samarappuli, L, Herath, H M L K and Abeywardene, O V 
P K K S Gunarathne et al.

(2012). Will smallholder rubber farming be viable in Monaragala district? Evidence from status of existing rubber lands. In: Proceedings of the Fourth Symposium on Plantation Crop Research - Technological Innovations for Sustainable Plantation Economy. pp. 371-383 (Eds. L.S.K. Hettiarachchi and I.S.B. Abeysinghe) Tea Research Institute of Sri Lanka, St. Coombs, Talawakele, Sri Lanka.

Wijesuriya, W, Dissanayake, A, Samarappuli, L, Wijeratne, M, Gunaratne, $\mathrm{K}$ and Abeywardene, V (2008). Issues and perspectives of smallholder rubber farmers and possible solutions for sustainable rubber farming in non-traditional rubber growing areas. In: Proceedings of the Second Symposium on Plantation Crop Research - Export Competitiveness through Quality Improvement pp.247-257 (Eds. N.P.A.D. Nainanayake and J.M.T.D. Everad).
Coconut Research Institute of Sri Lanka, Lunuwila, Sri Lanka.

Wijesuriya, W, Dissanayake, D M A P, Herath, H M L K and Gunarathne, P K K $S$ (2011). Constraints in sustainable smallholder rubber farming in the Moneragala district. Journal of the Rubber Research Institute of Sri Lanka 91, pp.61-73.

Williams, D L and Wise, K L (1997). Perception of Iowa secondary school agricultural education teachers and students regarding sustainable agriculture. Journal of Agricultural Education 38(2), 15-20.

Address for correspondence: $\mathrm{Mr} \mathrm{P} \mathrm{K} \mathrm{K} \mathrm{S}$ Gunarathne, Advisory Officer, Advisory Services Dept., Rubber Research Institute of Sri Lanka, Telewala Road, Ratmalana, Sri Lanka.

e-mail: kapila.s.gunarathne@gmail.com 